\title{
THE CITY OTHERWISE: The Deferred Emergency of Occupation in Inner-City Johannesburg
}

\author{
MATTHEW WILHELM-SOLOMON \\ University of the Witwatersrand \\ (iD) https://orcid.org/0000-0001-9946-5817
}

In August 2017, the mayor of Johannesburg, Herman Mashaba, in the international business publication Bloomberg, announced a campaign of "shock and awe" in inner-city Johannesburg, pronouncing the city a "battlefield" (Mkokeli 2017). The particular target of his rhetoric was the city's so-called hijacked buildingsunlawful occupations also known as "bad buildings" or "dark buildings." Mashaba, a former cosmetics businessman, who had grown up in poverty (Mashaba and Morris 2017), had won Johannesburg for the pro-business opposition party the Democratic Alliance (DA), defeating, for the first time in the post-apartheid era, the African National Congress (ANC). Mashaba, who as a young man had experienced the continued violence and insecurity of police raids, adopted raids as a primary strategy in his approach to issues of crime and housing in the inner city. He personally led a series of police raids on inner-city occupations and railed against both immigrants and human rights lawyers. He portrayed hijacked buildings as a blight on the city, full of criminals and undocumented migrants.

But what were these buildings, and who occupied them? How is one to understand the character of this occupation? And what did closing them imply? Where were the occupants to go? 
Some of these questions were answered, though not without problems, through the course of protracted social, political, and juridical processes. In December 2017, the Constitutional Court issued a judgment in a long-running case against the City of Johannesburg regarding a shelter for those relocated from an unlawful occupation. The shelter went by the name of Ekuthuleni, or Place of Peace. The case bore the name of Nomsa Dladla, a grandmother who was the first appellant in the case. The residents of Ekuthuleni were former occupants of a "hijacked building" who had received "temporary emergency accommodation" (TEA) as a result of a Constitutional Court order. However, the conditions at the shelter required gender division, curfews, and daily lockouts - conditions to which Dladla, her neighbors, and their lawyers objected. In November Dladla and her neighbors won the case, with the court finding that living conditions relating to lockouts were "cruel, condescending, and degrading." The occupants had been living in this TEA for more than half a decade after being relocated.

While the court case against the city began under the previous ANC administration, it was intimately connected to Mashaba's raids. Both spoke to the continued challenge of unlawful urban occupations in post-apartheid South Africa. Emergency housing was closely tied to "unlawful occupations," as I term them here: under post-apartheid constitutional law, occupants could not be evicted if that rendered them homeless, so the city was required to provide them with TEA. The issues of unlawful occupations and emergency accommodation question the meanings of home in the post-apartheid city, but also, globally, the contradictions between private property and socioeconomic rights.

Neither unlawful occupations nor TEA can be considered urban commons, but they do not constitute private property either. Instead, they emerge in the interstices of constitutional law, in a zone neither public nor private, in what I term "the city otherwise." I mobilize Elizabeth A. Povinelli's (2011, 2014, 2016) concept of the "otherwise" to characterize inner-city occupations and sites of TEA as spaces of endurance, improvisation, and potentiality (see also Simone 2019) that emerge within the aporias and contradictions of capitalist development and constitutional jurisprudence, though they may not necessarily form in opposition to capital, law, and the state. The city otherwise emerges within the wider juridical condition of what I term the "deferred emergency." The deferred emergency entails the indefinite deferral of an emergency situation, framed around both the juridical and infrastructural form of TEA, which has no legally defined end point. Furthermore, the long-term legal processes around TEA frequently require and sustain indefinite periods of unlawful occupation. The deferred emergency must be distinguished, 
first, from the legal term emergency, as in a "state of exception" involving the "suspension of law itself" (Agamben 2005). Second, the deferred emergency must also be distinguished from both the humanitarian "emergency" requiring responses to "war and natural disaster" (Redfield 2013), and, although related, from the everyday "tyranny of emergency" experienced by communities under threat of eviction or displacement (Appadurai 2001; Perdigon 2015). The deferred emergency arises instead from the legal and political strategies in which the emergency of eviction itself is deferred to an indefinite spatial and temporal horizon and not definitively resolved. The deferred emergency, as I will discuss, furthermore constitutes not merely a state of legal indeterminacy but also has infrastructural, policy, and existential implications.

I explore here the paradoxes of inclusion and exclusion shaped by post-apartheid urban renewal and policy, unlawful occupation, and emergency accommodation based on long-term, multisited ethnographic fieldwork conducted between 2011 and 2019 in unlawful occupations and TEA sites, among others, in Johannesburg. Though situated in Johannesburg, South Africa, this essay speaks to a broader condition and theory of occupation and the relations between housing, law, and life in the urban South (Simone 2019).

An anthropology of the otherwise requires confronting the "singular conditions under which something new is produced" (Povinelli 2011, introduction). This resonates with what João Biehl and Peter Locke (2017) outline as an "anthropology of becoming," in which both the subject and the object of research remain incomplete. My own ethnographic encounter with the city of Johannesburg is also embedded in personal becoming. I was born and raised in Johannesburg, and have lived in the city for the past nine years, working at an inner-city public university after returning from my doctoral studies abroad. The ethnographic character of my research has not been demarcated into discrete spatial and temporal zones. Instead, the research process has shaped and reshaped my pathways, forms of navigation, and dwelling in the city (McFarlane 2011b). It has involved constant orientation and disorientation in the city. As a white, male, middle-class South African, I have found the research process haunted by the specter of white violence, its spatial remainders and ruins on the landscape of the city (Harrison et al. 2014; Dirsuweit and Wafer 2016). To navigate the sites of occupation, I have relied on personal alliances and friendships formed over several years. I have worked at times with a research assistant who has helped with setting up interviews and translating from southern African languages. ${ }^{1}$ The article presented here distills this research, illustrates the proposed concepts with reference to case studies of both an occupation 
and a TEA site, and closes by exploring the political potentiality of these spaces through an emergent activist group called the Inner City Federation. ${ }^{2}$

\section{OCCUPYING JOHANNESBURG}

With the end of apartheid came the departure of many white-owned businesses and residents from the inner-city area to the suburbs, frequently leaving vacant space or buildings that were rented but poorly maintained. This phenomenon was eclipsed by the movement of many low-income black households into inner-city areas. Yet while wealthier suburbs became increasingly racially diverse, inner-city areas became primarily occupied by black Africans (Katumba 2019). In addition to this, the city experienced an increase in transnational migration, mainly from African countries. While documenting inward migration is challenging, available data estimate that 26.2 percent of inner-city residents are foreign nationals, far below the 80 percent claimed by Mashaba in the media (Skosana 2017). The absence of adequate urban housing policy in South Africa means that tens of thousands of inner-city residents, both South African and foreign nationals, cannot afford decent housing and are forced to live unlawfully in occupied buildings.

Achille Mbembe and Sarah Nuttall $(2008,22)$ have divided the social topography of Johannesburg into the domains of the "surface" and "the underground," or necropolis, characterized by the "lower classes, the trash heap of the world above, and subterranean utopias." Despite this image's compelling nature, unlawful occupations do not fit neatly into this topography. While the city is undoubtedly composed of "other orders of visibility" (Mbembe and Nuttall 2008, 23), unlawful occupations are not infrastructurally, legally, or socially "underground." Neither do they exist in a "state of exception" outside of the law (Murray 2008). Their existence has been highly mediatized, often through a lens of migration and criminality and in public court cases. Furthermore, they do not offer a "subterranean utopia," but rather, often, fractured modes of sociality and inchoate forms of political activism.

The perpetuation of conditions of extreme dereliction goes along with the development of new commercial and arts precincts, in what Chrystel Oloukoï (2018) has labeled "precarious gentrification," characterized by the paradoxical and oscillating movement of "taking back the city," which simultaneously structures itself around the fear of the nighttime city and the darkness. Further, changes in the city have not primarily resulted from paradigms of middle-class gentrification, but have involved the building of tens of thousands of units of accommodation for 
middle- and low-income households (Mosselson 2019, 41), though most of these still prove too expensive for the residents of unlawful occupations.

The term hijacked building, indicating a formal criminal seizure, is mostly misleading, though cases of criminal takeover, or title-deed fraud in attempts to claim ownership, do exist. Unlawful occupations are also known as "bad buildings" in policy documents and sometimes as "dark buildings" by inner-city residents, indicating the lack of electricity in many of them. Criminal activity, such as drug trading, is evident, but mostly practiced by a minority of occupants of some unlawful occupations. Most residents are informal workers, such as street traders and recyclers, along with the unemployed, including beggars, many of whom are disabled. Residents of unlawful occupations frequently experience evictions (in spite of legal protections), police raids, and, for foreign nationals, deportation. Fires and accidents are common, and residents must survive amid the ruination of urban infrastructures (Wilhelm-Solomon 2017; cf. Chance 2015). With little police protection residents themselves are often subject to criminal violence. Gender-based violence is common - this reflects wider patterns of power, exclusion, and shame permeating post-apartheid South Africa and inherited from the country's violent colonial and apartheid past (Gqola 2015). Nonetheless, unlawful occupations are also spaces of homemaking, conviviality, and intimacy.

Many of these occupations fell slowly into dereliction when businesses or their owners left or died. Often previous building administrators used the opportunity to collect illicit rent, or residents boarded up vacant space to rent. In some cases, vacant and abandoned spaces slowly become occupied. No reliable surveys or estimates exist of total residency of unlawful occupations in Johannesburg, though in 2010 Médecins sans Frontières (MSF) estimated that 50,000 to 60,000 people lived in inner-city "slum buildings," in conditions lower than international standards for refugee camps. The organization began work in the buildings, responding to a perceived humanitarian emergency, but withdrew when faced with funding concerns and the entrenched structural crises of housing, immigration, and urban exclusion (Wilhelm-Solomon and Pedersen 2017). Census data from 2011 indicated a housing shortage of 30,000 units for precarious inner-city households, many of whom would be presently living in overcrowded or unlawful conditions (RebelGroup 2016). Internal documents of the City of Johannesburg estimate that as many as 90,000 people may be living in unlawful occupations. ${ }^{3}$ As of 2018, the city only catered to 1,364 individuals in TEA facilities, at capacity at the time. This represents but a small fraction of potential evictees. The lack of available TEA delayed the evictions of numerous unlawful occupations in the inner city. 
Because unlawful occupations are highly stigmatized and criminalized, research is slow and frequently fraught. These spaces operate neither through formal property regimes nor through easily legible systems of control, rental, or occupation. In work parallel to my own, Jackie Dugard and Makale Ngwenya (2018) have argued that we cannot grasp these buildings in terms of standard understandings of civic movements or "the right to the city" (Lefebvre 1996; Harvey 2008), and that the occupants in their cases primarily follow survivalist strategies and desire formalization. Most of the residents of unlawful occupations do not participate in the form of political squatting prominent in Berlin, for instance (Vasudevan 2017), nor in the politically motivated occupations extant in places like São Paulo (De Carli and Frediani 2016; Stevens 2017). I use the term "unlawful occupation," instead of "hijacked building" or "bad building," in a sense motivated by Filip De Boeck and Sammy Baloji (2016, 297): occupation does not invoke "the formal claim of a political right to the city," though it may end up doing so; rather, the "politics of occupation is part of an even more basic and fundamental (and therefore even more deeply political) claim: the simple claim to be, to stake out a place for yourself, to exist."

From a methodological perspective, Nishat Awan $(2016,3)$ has used the phrase "mapping the city otherwise" to emphasize "relations over discrete objects, subjectivities over essential identities, and a provisional politics over ideology," as well as to explore the "affective body and its sensations that allow us to access the field of potentiality" (Awan 2016, 35). She does not cite Povinelli's work, though she shares the latter's concerns around affect and potentiality. While sensitive to this approach, the concept of the city otherwise I develop here is not merely methodological. ${ }^{4}$ The city otherwise points to interstitial urban spaces that emerge within the aporias and contradictions of real-estate markets and the constitutional nation-state, though they do not conform to the governance of either. The modes of living otherwise are both precarious and subject to the enduring threat of erasure. Residents of occupations are only sometimes involved in formalized civil or legal mobilization; often they aim to evade state governance and participate in tactical alliances (Simone 2004, 2019; Vearey 2010; Wanjiku Kihato 2014).

\section{SITUATING THE CITY OTHERWISE}

To conceptualize the city otherwise, it is valuable to situate and contrast it with several other related concepts prominent in urban theory-namely the so-called commons, heterotopia, and the assemblage. The idea of the commons and "commoning," have become some of the central concepts in urban theory. 
Nonetheless, given the fluid, incomplete, and often fractious dynamics of urban life, scholars have retheorized the commons as a form of potentiality embedded in emergent socialities, rather than in terms of a collectively managed and regulated urban space (Simone 2014; Berlant 2016; Worby, forthcoming). Eric Worby (forthcoming) in particular has highlighted the peculiar temporality of how political actors frequently theorize and mobilize the commons. He writes that "the commons typically signifies an idealized past and a utopian future - as much a lost right to be claimed as a social entitlement to be regained.” This particular temporality of the commons - frequently trapped between nostalgia for a lost past and the hope for a potential future - points toward the way the commons frequently remains a transcendental, teleological, or nostalgic form.

The shift to the otherwise, moving away from the language of the commons (whose heuristic or political power I do not deny) involves a shift from transcendental to imminent critique. Imminent critique in urban theory has been most prominently explored in the concepts of heterotopia and the assemblage. Michel Foucault $(1986,24)$ characterizes heterotopias as "countersites" and "a kind of effectively enacted utopia." Urban theory has mobilized and adapted the concept to a wide variety of sites, including migrant and refugee encampments (Olga 2013; Perdigon 2015), an inner-city theater in Johannesburg (Miranda da Cunha 2019), and urban religious sites (Bochow and Van Dijk 2012), among others. Of particular significance to the discussion here is Danny Hoffman's (2017) critique of Partha Chatterjee's (2004) use of the concept in relation to unlawful urban occupations. The concept of heterotopia has informed Chatterjee's (2004) influential notion of the "politics of the governed." Chatterjee $(2004,40)$ argues for a concept of "political society" that extends beyond standard models of civil society and may include those who "transgress the strict lines of legality in struggling to live and work," including "illegal squatter settlements" and those who "make a claim to a habitation and a livelihood as a matter of right." Hoffman (2017), whose ethnography focuses on several unlawfully occupied spaces in Monrovia, including large modernist edifices and a cemetery, and who conducted his ethnography with many ex-combatants now involved in forms of hustling, scams, and crime, rejects the notion of heterotopia, arguing that while these occupations constitute "spaces of invention, experimentation and serious play ... they are not heterotopic in the Foucauldian sense or any of its derivatives. These forms of intervention are circumscribed for the most part by a very limited political imagination and a very narrow set of material possibilities" (Hoffman 2017, chap. 1). Hoffman's critique usefully points to the limitations of the concept of heterotopia, as well as to its reliance, even if in 
a disruptive sense, on some form of utopian political imaginary. Yet he proceeds from this insight to define unlawful occupations as spaces of "urban subjection," an account I find inadequate, at least for theorizing unlawful occupations more widely.

Povinelli (2011, introduction) acknowledges her debt to Foucault's notion of heterotopia, and the tradition of imminent critique (see also Perdigon 2015), but her conception of the otherwise significantly advances beyond the concept. The otherwise is not premised on the heterotopic idea of either "society itself in a perfected form" or "turned upside down" (Foucault 1986, 24) — it emerges from within social interstices in a manner neither utopic nor oppositional. Furthermore, the concept is not premised on an idea of the political imagination or "will"subjects may form part of a social project within "spaces of the otherwise" involuntarily. Contra to Hoffman's account, in which a lack of political imagination excludes such spaces from the political, for Povinelli (2014) politics may merely constitute a gesture toward articulating the otherwise: "Politics is the adventure of the otherwise as it becomes (or does not) a self-referential, extended, and dominant entity-arrangement.” Furthermore, whereas Hoffman sees the lack of political imagination and material limitations in terms of a form of privation, Povinelli sees imagination discrete from potentiality. She is precisely concerned with moments in which an alternative social project is "neither something nor nothing" and with "the virtual space that opens up between the potentiality and actuality of an alternative social project."

Where the analytic clarity and subtlety of Povinelli's (2011, 2014, 2016) thought is distinct from both theories of the commons and of heterotopia is precisely in her theorizing of potentiality - in particular, the potential to resist late liberal and neoliberal hegemonies - in a manner not premised on ideational, utopic, or teleological imaginations. Rather, she considers potentiality in terms of the spacing between the "striving to persevere" and "any actual idea or action that emerges from this striving" (Povinelli 2011, introduction). The otherwise precisely captures the "immanent derangements and rearrangements" of a given assemblage - it is the "noise" that emerges from within the fissures of particular power arrangements (Povinelli 2014).

Povinelli's work here has a clear, but unexplored, affinity with the emergence of assemblage theory in urban studies. Assemblage theory concerns itself with theorizing the urban in relation to a heterogenous concatenation of human and material forms (McFarlane 2011a), and it shares a theoretical basis with Povinelli in Gilles Deleuze and Félix Guattari's concept of agencement and a concern 
with imminent potentialities. Ignacio Farías (2011) has argued that the political implications of assemblage point toward a more radical, object-oriented participatory democracy. Expanding on this argument, he has more recently interrogated the political potentialities of "urban cosmopolitics" concerned with the "heterogenous constituents of common worlds," which "is what happens at the interstices, in the conflictual clashes and tentative accommodations of multiple urban worlds" (Farías and Blok 2016, 14). What sets Povinelli apart from these formulations of assemblage theory is that she evades the idealism implicit in expanding a normative democratic notion to encompass non-human actors in the search for "common worlds" (Farías and Block 2016). Rather, she focuses on the contingency and emergence of alternative social projects within the paradoxes and ruptures of hegemonic assemblages - the moments and spaces of dissensus where "what we had in common is no longer common" and inchoate collectivities take form (Povinelli 2016, 124). The potentiality to live otherwise is political, not in relation to some democratic ideal, but precisely through enduring the forces that work to disarticulate and silence it. Spaces of the otherwise are constituted by everyday "quasi-events" and by "intense daily struggles" that are "barely perceptible" in the political language of late liberalism (Povinelli 2016, 21).

The indeterminacy and deferral characteristic of these struggles are not unique to housing but form part of a wider condition affecting an array of people, including asylum seekers in South Africa, for instance, as well as precarious populations globally (Ralph 2008; Allison and Piot 2014; Perdigon 2015, 2017; Das 2017; Fassin, Wilhelm-Solomon, and Segatti 2017; Wafer 2017). Yet, the deferred emergency can be distinguished from the bureaucratic deferral of the asylum system and the more generalized condition of waiting produced by the economic exclusion of neoliberalism. Deferral here does not result only from bureaucratic delays and postponement, but instead arises as a necessary mechanism to balance the apparently irresolvable rights of both property and protections against homelessness.

Here, I think one can further Povinelli's work with a critique of Giorgio Agamben. In his reflections on Aristotle in Potentialities, Agamben (1999) distinguishes two forms of potentiality in the Greek philosopher's work: a generic potentiality (a child could potentially become a president) and a specific potentiality (an architect has the potential to build, a poet to write poetry). Agamben notes that in Aristotle, potentiality exists not only in opposition to actuality but also as a characteristic of the actual, the capacity to exist in privation. However, the work of Povinelli points toward a notion of potentiality not solely characterized by pri- 
vation. Rather, potentiality can indicate the capacity to live otherwise within the urban assemblage.

\section{THE DEFERRED EMERGENCY: Life in Potentiality}

To elaborate on this in light of contemporary post-apartheid constitutional law, we can begin by observing that the law outlines not merely a set of cast-instone rights but also a set of potentialities regarding what it means to be human. We see this, for instance, in section 26 on housing:

26. Housing. (1) Everyone has the right to have access to adequate housing. (2) The state must take reasonable legislative and other measures, within its available resources, to achieve the progressive realisation of this right. (3) No one may be evicted from their home, or have their home demolished, without an order of court made after considering all the relevant circumstances. No legislation may permit arbitrary evictions.

Constitutional law inscribes a set of both specific and generic potentialities (the former in, say, the right to housing, the latter in the right to dignity. Regarding the phrase "progressive realization," many South Africans - in fact, potentially "everyone" within South Africa's borders unable to secure housing, including foreign nationals - live not simply without housing but also in a condition of both privation and juridically protected potentiality. The right to access housing does not constitute an immediately enforceable right in the sense of the right not to be killed, or the right to freedom of speech. Rather, it is a right in potential, one that can be deferred but not annulled. This has substantive material consequences, as my ethnography to follow shows.

In October 2017, on a cold spring day, I stood outside the site of 7 Saratoga Avenue with Nomsa Ellen Dladla and one of her neighbors. We looked through the barbed-wire fence at a courtyard and an abandoned red-brick carpet factory. This cordoned-off, derelict space had been my two interlocutors' home before they were relocated in 2012. The building was an unlawful occupation, one to be catapulted to the center of post-apartheid housing jurisprudence. "We were free, were free," Dladla told me when I asked what life had been like here, in the unlawful occupation. The meanings of her words would only become clear in the context of what was to come.

The factory had closed in 1999 and had subsequently been unlawfully let by the former caretaker. Then a company called Blue Moonlight purchased the 


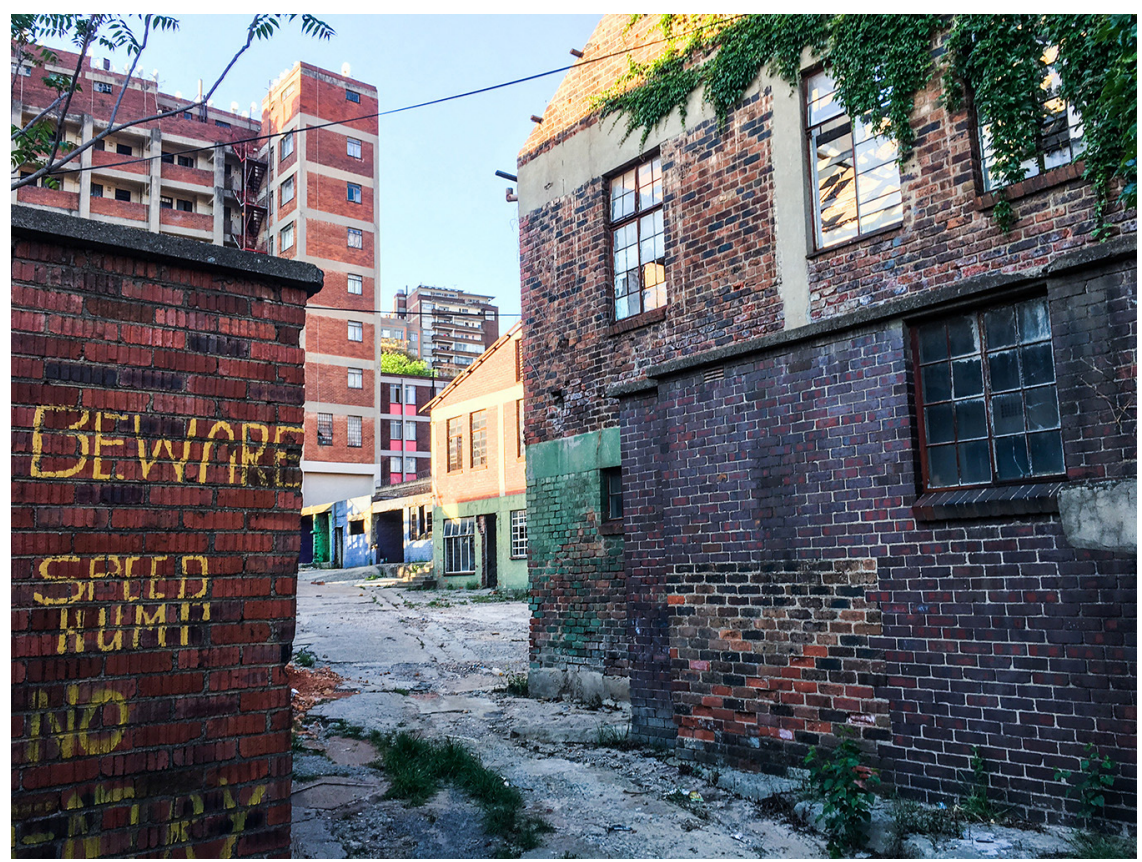

Figure 1. The now-empty carpet factory of 7 Saratoga Avenue, the center of the Blue Moonlight case. Photo by Matthew Wilhelm-Solomon, 2017.

building in 2004 and in 2006 started eviction proceedings. In 2007, police and the Red Ants, notorious private security, attempted to illegally evict, using rubber bullets, the sixty-two adults and nine children resident at the time. The community, primarily Zulu, had often used the communal courtyard for chatting, cooking, parties, and dances. But on the night of the eviction, Dladla, her granddaughter, and her neighbors spent the night on the street. They did have legal representation through the Centre for Applied Legal Studies, however, which blocked the eviction on the basis of it leading to homelessness. This change instigated a period of litigation that would last five years, until the famous Blue Moonlight case was heard in the Constitutional Court and judgment was given in December 2011. ${ }^{5}$ During the legal proceedings, the City of Johannesburg was tied to the case.

Stuart Wilson, one of the leading lawyers acting on behalf of the occupiers in the case, has argued that, until this case, the city had relied on the strategy of having private-sector actors evict residents of "bad buildings." Yet the Blue Moonlight case had the key implication that "the municipality bears the primary responsibility for addressing the housing needs of those persons who, after an eviction, are unable to find accommodation on their own" (Wilson 2013, 283). The judgment reshaped the city's obligations to those dispossessed by evictions, but also fore- 
stalled evictions that would lead to homelessness. Furthermore, it reshaped how both policy and jurisprudence would frame the "emergency."

According to the Constitutional Court judgment, the case bore on "questions of eviction" and it revolved not around the provision of permanent accommodation but rather "temporary emergency accommodation." The concept of the emergency here specifically relates to a pending eviction leading to homelessness, not necessarily one already carried out (even while the occupiers of Saratoga were temporarily evicted). The judgment drew on definitions from Chapter 12 of the National Housing Code, which defined eviction in terms of emergency as affecting those "evicted or threatened with imminent eviction from land or from unsafe buildings, or situations where pro-active steps ought to be taken to forestall such consequences." Yet the National Housing Code also characterizes emergencies in a manner that includes homelessness as a result of natural disasters; hence, the law considered eviction in the same legal category as natural disasters and humanitarian emergencies (cf. Redfield 2013). This has not merely semantic implications but also significant perlocutionary consequences.

In 2012, the residents of 7 Saratoga were moved to Ekuthuleni, a shelter run by an NGO called MES (formerly the Metropolitan Evangelical Services). The shelter was meant only as a temporary solution, and the residents believed they would stay there for six months only. Yet a permanent settlement never came on offer, nor did the court direct the need for one. Life at Ekuthuleni proved harsh. At the overcrowded shelter, in which a series of dormitories surrounded an inner courtyard, the residents found themselves locked out between 8 a.m. and 5:30 p.m. and again after 8 p.m. if they failed to return to the shelter by then. The rooms were gender differentiated, separating even married and long-term couples. The rooms lacked locks, and shelter authorities randomly searched belongings. Social workers took Dladla's granddaughter (whose mother had died) into foster care as the shelter did not provide family accommodation - and she was only allowed to return to live with her grandmother over three years later.

The residents, supported by their lawyers, now the Socio-Economic Rights Institute of South Africa (SERI), challenged the lockouts, gender divides, and the breakup of families. The judgment of the case named after Dladla in November 2017 found the shelter rules to be "cruel, condescending, and degrading" in that it treated grown people "like children." The judgment stipulated that TEA still conferred a right to dignity and family intimacy - the shelter and other TEA providers consequently could not simply ascribe to the minimal conditions of a refuge. Even though the residents had previously lived in a "dark building" and now had 
electricity, they struggled with life in the shelter. Dladla told me: "Nothing is alright here. There are many tsotsis [criminals], nothing is OK. I would like a place called my home. . . . It's not safe this place.” The judgment forced the municipality to alter its policies and the shelter to abandon its rigorous rules, but it did not resolve the situation of housing. Dladla and her neighbors still lived in conditions of uncertainty, in a temporary space with no practical possibility of obtaining permanent housing. It is such a condition that I call the "deferred emergency," one in which eviction and homelessness are prevented indefinitely, with no permanent solution on offer.

The conditions of TEA, while arising from constitutional protections against homelessness, had become a condition of partial state care and partial abandonment. No constitutional or policy-based limitations bounded the TEA time frames, and this question had never been legally probed. Given that the provision of TEA aimed to protect against homelessness in the first place, evictions of those already in TEA — should they lead to homelessness — could hardly be constitutional. Since many people cannot afford access to the formal housing markets, TEA has in effect become a permanent facet of life in Johannesburg: TEAs constitute "spaces of otherwise" in that they offer housing and refuge to those excluded from real-estate markets; they are materializations of a social vision in which nobody is homeless. Yet they fail to offer any permanent solution to homelessness, constituting sites of struggle and endurance.

Life in such spaces requires from people like Nomsa Dladla a constant state of perseverance, innovation, and struggle. The residents live in the territory of the otherwise, having fought for state-funded protection and care, but having never been fully granted the right to stable residency and a home. The Blue Moonlight and Dladla cases, and the effects of TEA more generally, shape life not only in the TEA facilities themselves but also in unlawful occupations with pending eviction cases, such as The Station, to which I turn now.

\section{ENDURING THE OTHERWISE: The Station}

The Blue Moonlight and Dladla cases affected many unlawful occupations throughout Johannesburg, whose eviction cases were postponed pending the Dladla judgment. One of these was a building I call The Station, which I visited between 2014 and 2019: I observed how everyday life under the deferred emergency revolved around washing, recycling, trading, drinking, and police raids. Rather than marked by rebellion against a status quo, everyday life was patterned by endurance and exhaustion (cf. Povinelli 2011; Simone 2019). 


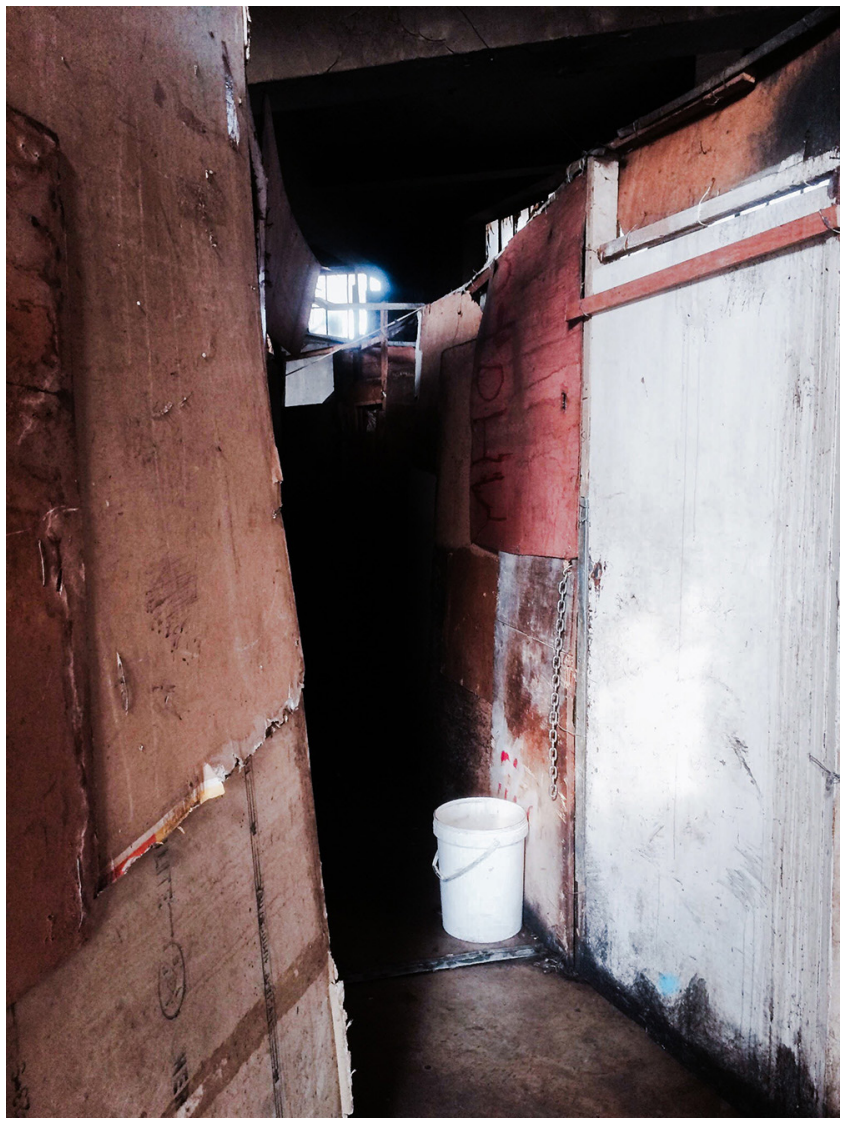

Figure 2. The interior of The Station. Photo by Matthew Wilhelm-Solomon, 2017.

The Station was a previously formally rented 3,000-square-meter building that had fallen into disrepair and was sold, occupied, to an inner-city property developer in August 2007. A changing cast of around three hundred people makes up the residents of The Station; they include both South Africans and Zimbabweans, more than fifty of whom the residents' committee estimated to be blind.

The Station's several floors are partitioned with boarded rooms beneath a spider web of electrical cables. These rooms were sometimes bought and sold on an illicit retail market, rather than unlawfully rented, as in the case of some other unlawful occupations. The building has only one tap on the ground floor, beside a storage area where recyclers store what they have gathered. With no toilets in the building, residents must use buckets, or the local public toilets. Laundry is done mainly on the pavement or rooftop, which overlooks nearby train lines, where it is hung out to dry. In the mornings many of the residents disperse through the 
metropolis. Most of the blind head "to the robots" (South African slang for traffic lights) _ a euphemism for begging. Other young men might also sell commodities like phone chargers at intersections. Recyclers, mostly men but some women, chart the surroundings with metal carts. Many of the women spend their days sitting on the pavement or on public concrete benches, caring for children, doing laundry, braiding hair, and selling snacks on the street corner-but they also stay outside so they can run away if the police come.

Several informal taverns or shebeens make for centers of social life. Drinking would often begin mid-morning. I spent many hours in the shebeen of Rosemary Mavundla, a member of the residents' committee and a Zimbabwean woman whose son had been murdered in 2014 while buying beer; the killers were never found. For the funeral, networks activated throughout the city to have members gather in her room to sing and care for Mavundla. Sadly, funerals made for a source of diasporic sociality (Wilhelm-Solomon 2020). On other occasions, I chatted with her and friends or clients as they drank, smoked ganja (cannabis), and watched music DVDs. The shebeen also served as Mavundla's bedroom, adorned with posters from clothing stores. She would cook a lunch, to sell or share, of maize meal, spinach, sweet potatoes, and sometimes offal. In the cold of winter, she and her friends and clients would gather around the stove, warming themselves on the illegal electricity. Her shebeen was closed in 2016 when the city cut off the illegal power supply, plunging residents into a perpetual interior darkness.

Before, police would come to Mavundla's shebeen (among others), frequently on Fridays to collect crates of beers for the weekend. Sometimes they would violently raid the building, such as at a birthday party where they fired rubber bullets and stole speakers and equipment. An immigration raid in March 2014 seemed a thinly veiled attempt to evict residents by proxy, as the local area manager for the owners was present. But most of those deported returned immediately; the concatenation of political persecution, drought, and economic collapse in Zimbabwe made life there unendurable for many. Many members of the Movement for Democratic Change (MDC), Zimbabwe's opposition party — whose representatives had suffered frequent political persecution from the ruling Zimbabwean African National Union-Patriotic Front (Zanu-PF)—-lived in the building. Their local branch would meet in a small square nearby.

Unlike in some other unlawful occupations, no gangs operated out of The Station, but the residents were at times persecuted by criminals. In late 2014 a group of men started terrorizing and robbing the residents, encouraging some of the residents to collaborate with a local private security initiative, employed as 
part of the privatized City Improvement Districts initiative (ironically, funded in part by the evicting company). Together they took one of the men behind this harassment to the police, although the residents later dropped charges in a truce. Other examples of collaboration with the police existed: for the blind, the noise of the shebeens destroyed the transient peace they, with their peculiar sensitivity to noise, could enjoy, so their leader reported the shebeens to the local police and supported the raids on them. Conflict never, however, spiraled out of control, and residents maintained a semblance of peace through an ever-shifting dance with criminals, private security forces, and the police, with the roles of ally and enemy often rotating.

The police would rarely, however, arrest the blind who had moved into the building after the 2008 xenophobic violence that had erupted in Johannesburganti-immigrant violence spread throughout city and the country leading to over sixty deaths and 100,000 displaced nationwide (Landau 2011). Many inner-city migrants were forced to take shelter at a local police station. In the wake of the violence, many of the blind, along with other affected groups, moved into The Station, because it offered vacant space. Among these was Emmanuel Zivai, who would come to lead the blind and be the residents' chairperson. Zivai's room, on the first floor, was crowded with buckets and clothes. Each morning he would leave the building with a helper and take a taxi out to the Indian township of Lenasia on the western outskirts of Johannesburg. Zivai, a former fish trader in Zimbabwe, had been elected leader in part because residents believed that the blind could not be evicted. This perception built on the experience of residents in a nearby building known as Chambers, where an eviction had been overturned because there were blind residents who were eventually offered alternative accommodation (see Wilhelm-Solomon 2016). Many members of the blind community knew each other from Zimbabwe-having attended Margareta Hugo School in Masvingo, a Dutch Reformed mission school providing schooling for blind learners - and they had come to South Africa when the Zimbabwean state radically cut disability support. These diasporic networks based around disability endured cross-border migration, evictions, and displacement from xenophobic violence.

These newcomers had to foster relations with established residents of the building; among these was Nomusa Mabaso, a retired cleaner and one of the few remaining South Africans. She had been on the list for state-sponsored Reconstruction and Development Programme (RDP) housing for many years, but never heard anything. The ANC government had built an estimated three million state houses (Wilkinson 2016), but primarily on urban peripheries far from work, and 


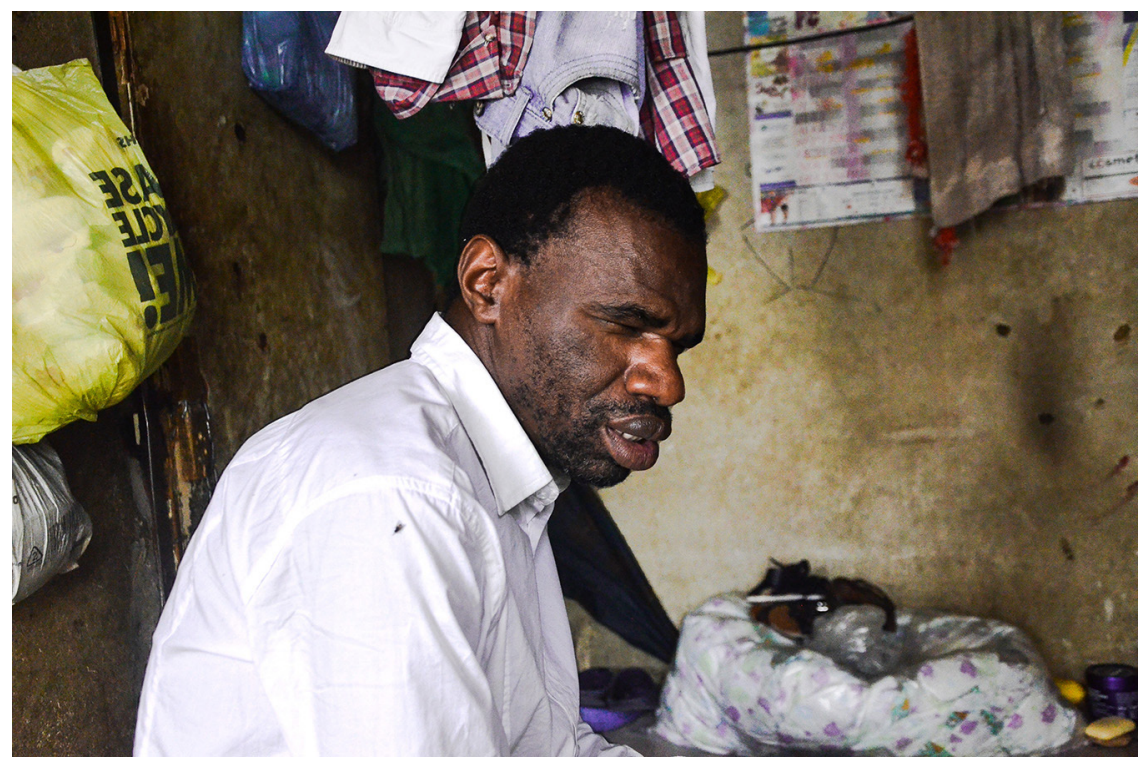

Figure 3. Emmanuel Zivai in his room at The Station. Photo by Matthew Wilhelm-Solomon, 2017.

millions of South Africans waited on these housing lists. Mabaso originally hailed from KwaZulu-Natal province and had lived in Soweto and Johannesburg since the 1970s, selling vegetables and working as a cleaner. The 1990s, with the arrival of a black government led by Mandela, were a period of hope for Mabaso. When she moved into The Station toward the end of the decade, the building was formally rented. It had security, electricity, and cleaning services, though there were no toilets or showers, and only one tap serving the building. Mabaso and her partner paid R500 for their room. After the owner of the building, a Swazi woman, died, conditions deteriorated. Mabaso, whose partner had died in 2013, built convivial relations with the Zimbabweans who had moved in, often eating and drinking with them. Yet she also associated their presence with the building's slow decay. She did not express any feelings of ardent xenophobia; rather her sentiments seemed pervaded by a sense of loss and hope disappointed, articulated sometimes as resentment of neighbors and strangers.

The property company that had purchased The Station attempted to evict the tenants in 2010. Yet the residents formed a committee comprising several asylum seekers, including the blind, and two South African pensioners. Mabaso, Zivai, and Mavundla all formed part of this committee. They managed to get pro bono lawyers to oppose the eviction. This tenuous alliance revealed the precarious potentiality of such spaces of otherwise. Their case went to court in February 2010, 


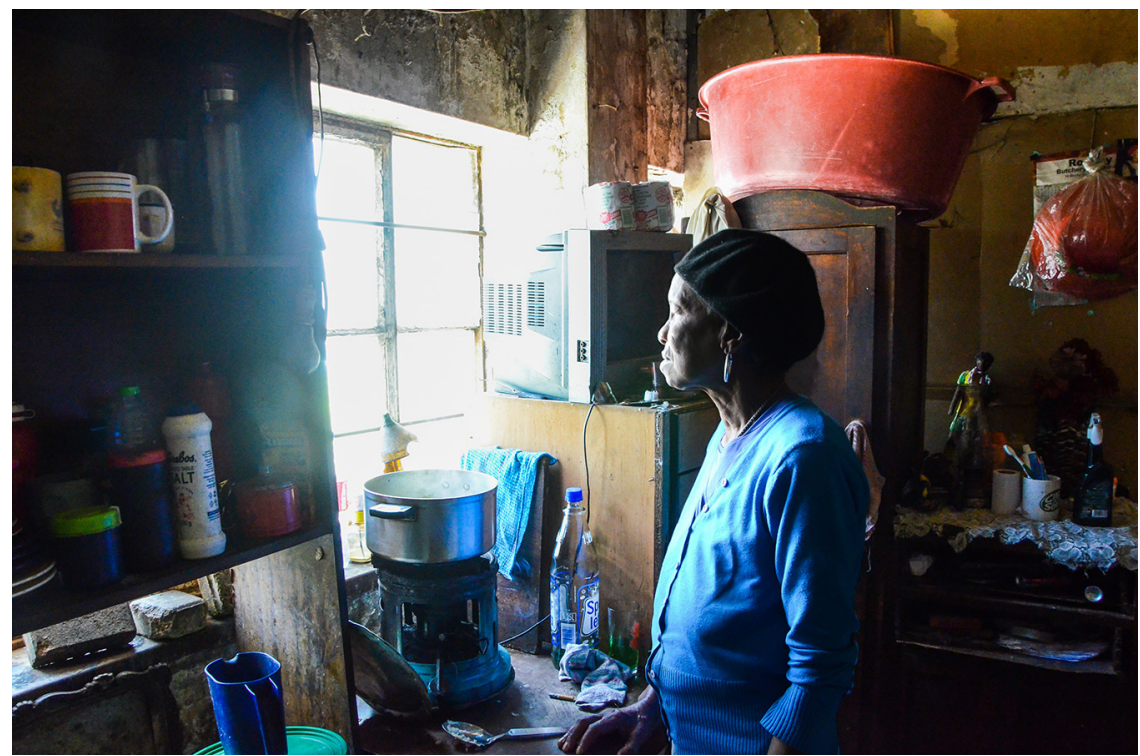

Figure 4. Nomusa Mabaso in her room at The Station. Photo by Matthew Wilhelm-Solomon 2017.

and the eviction was postponed pending the outcome of both the Blue Moonlight and (later) the Dladla cases. Ironically, the conditions of deferred emergency allowed residents a type of normalcy, with the majority of residents rejecting the possibility of relocation. This was exemplified in 2015, when the city provisionally offered TEA to the residents, in the form of a nearby warehouse with communal bathroom facilities, which they declined, unwilling to move from one temporary site to another.

When I asked Mavundla, the shebeen owner, why, she replied: "We are used to here." I also met with Zivai, who was planning to return to Zimbabwe with building materials he had collected to construct a house on family land. We chatted at a crowded bus terminal. He told me with resignation that he had no expectations of the South African state, but that he also could not survive returning permanently to Zimbabwe. When I asked him what he hoped for in the future, he replied simply, "That is hard for us to imagine."

The possibility of foreign nationals at the Station being offered TEA ended with the election of Herman Mashaba and the amplification of raids. Many buildings, even with court orders protecting against eviction, became targets, as did The Station. I did not witness Mashaba's raid in late 2017; several residents present at the time narrated it to me. Apparently, Mashaba arrived with an entourage of police, immigration officials, and the media. Police went from room to room, 
banging on doors and forcing them open. In part, this approach was intended to facilitate an audit of who was living in the buildings. Mashaba, a charismatic figure, spoke to some of those involved, including a number of blind foreign nationals, a heavily pregnant Zimbabwean (whom they assisted in taking to the hospital after breaking down her door), and Mabaso. The residents that spoke to him found the mayor open and attentive, giving a contradictory display of both care and force.

In late August 2018, a year after the raid, I went to visit Mabaso, the day before the city's final audit for TEA was due. Mabaso, slim and wizened, was in her room frying cabbage and chicken. On the floor lay a pile of dust where she had been sweeping, as well as a blue floral dress that had been eaten by mice. Mabaso was wearing a beige shirt with crisscrossing lines, a retro pattern often found in secondhand stores. Beneath it showed the top of the ANC spear. I asked her if she still supported the party. She coughed affirmatively, but added: "They lie. Nothing is happening for me. They lie. I'm tired. Things take time, but now it's too long." Mabaso had grown tired of living in The Station and longed for a permanent place to settle. She told me: "I spoke to Mashaba, and he promised he will do something. I've been waiting, waiting."

The following day, with city officials due to arrive for a final resident audit, I spoke to Zivai, who remained hopeful that the residents could remain together. Within The Station, the blind had formed their own otherwise - a space of sociality and care now under threat: "We are familiar to each other. We are now used to being with each other. We share everything. Life is so simple. It is good to stay together as long as life goes on." I also spoke to a group of MDC supporters, who feared that if they returned to Zimbabwe they would face political persecution; their expired asylum-seeking documents made them vulnerable both to eviction and to deportation.

Eventually, the city officials arrived in a BMW X1 - three men and two women wearing luminous jackets. A crowd gathered around the group. Mabaso was sitting on a plastic chair on the pavement. A man pointed to her, saying, "We have the details of this gogo [elderly lady; literally, grandmother]," marking her out as a South African. Zivai then appeared, and a dispute arose between him and the officials over the auditing process (he was concerned some had been left out). After some futile arguing, the officials entered the building led by a woman with braids and dark glasses who found her way with the light of a mobile phone. I followed. At one point, exasperated by the differences between a previous audit and the current one, the woman turned to me, claiming, "This is fraud. People 
are mushrooming on the second floor . . . It doesn't matter, register them. They're undocumented. They won't get accommodation anyway."

When the report was released it stated that only South Africans would receive alternative accommodation. The rest would, at some point, face eviction: they had lived for almost a decade in conditions of legal abeyance, as a result of the deferred emergency, in states neither entirely lawful nor unprotected - in the city otherwise. Mabaso would not live to see a new home: she fell ill and died in a hospital in early 2019, after having her leg amputated from septicemia. While she still remained at The Station Zivai, Mavundla, and her other neighbors visited her room and prayed for her during her illness, but few could afford the transportation costs to visit her in the hospital. As no family came forward after her death, Mabaso's body was not released for a funeral or memorial. The precarious character of life in the city otherwise can easily slide into conditions of almost total abandonment.

\section{AN URBAN POLITICS OF THE OTHERWISE}

For much of my research from 2011 onward, no organization collectively organized inner-city residents living in unlawful occupations. Some legal, church, and humanitarian NGOs operated on a case-by-case basis, but they did not have the capacity or mandate to develop an extensive mobilization among those on the ground. ${ }^{7}$ No organization existed along the lines of Abahlali baseMjondolo, who had mobilized shack dwellers first in KwaZulu-Natal and then nationwide from 2005 onward (see Chance 2015).

Yet in 2015, a change began to emerge. In March of that year, a new organization formed from a workshop among communities represented by the legal NGO SERI. Here, the residents themselves had decided to create a new organization, which they called the Inner City Federation (ICF). The organization gradually began to grow from the initial meeting, and by 2018, it represented more than forty occupations and thousands of occupants. It has developed strategies around cleanup campaigns, assisted in "maintaining communal infrastructure" (SERI and ICF 2018), mediated conflicts, helped tenants mobilize against eviction, and campaigned through protest and media campaigns for fundamental rights.

The organization sprang into existence at a meeting attended by residents' committees from throughout the city. The residents pitched the idea of a new organization that would serve as "a platform of sharing knowledge." Siyabonga Mahlangu would become the organization's general secretary. Mahlangu recalled to me: 
I felt so excited because I understood I was not the only one facing the problem, and I got knowledge from some other people who had experience. Now I knew that if I had a problem, I have this platform to go and say, "Guys look, I have this problem, how can I solve it?"

The new organization elicited a collective awareness and a sense of the political potential of life in the city otherwise.

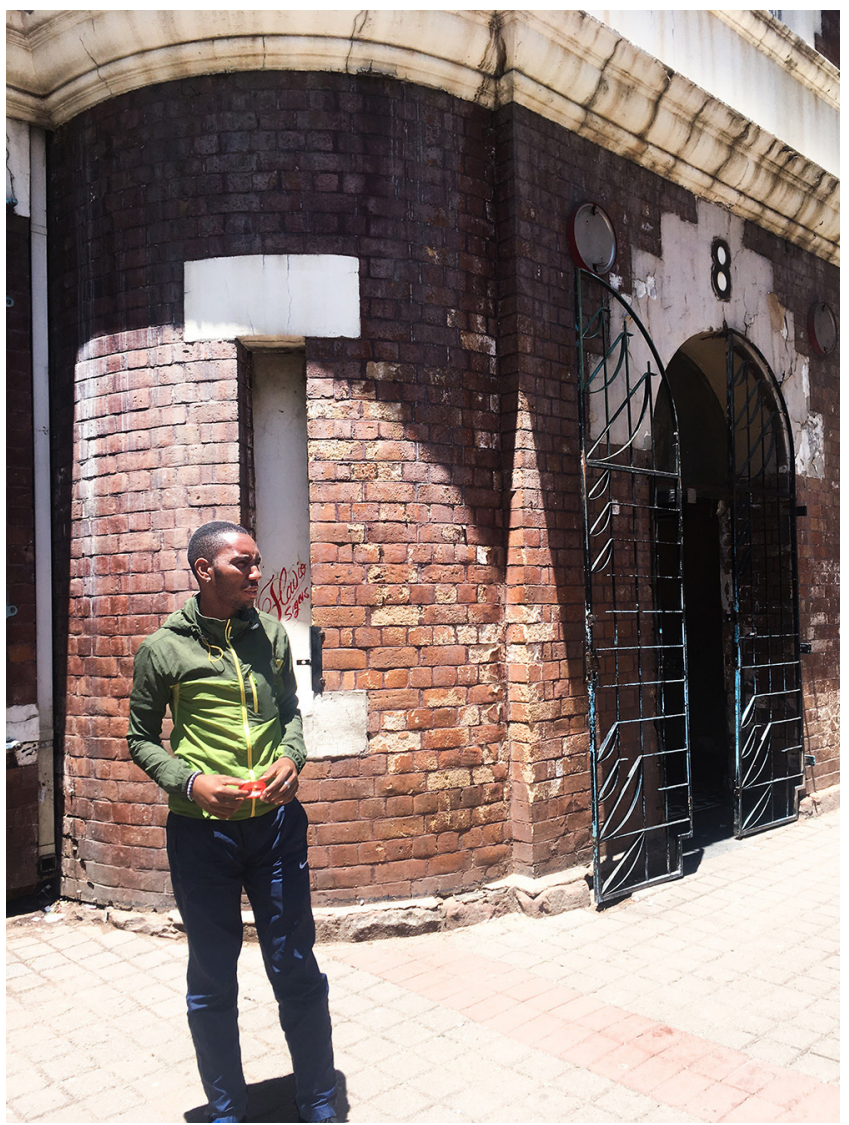

Figure 5. Siyabonga Mahlangu, General Secretary of the Inner City Federation, outside Ingelosi House-or "Number 8" to residents-in Hillbrow. Photo by Matthew Wilhelm-Solomon, 2017.

Mahlangu lived in a building called Ingelosi House, known to residents only as Number 8. Mahlangu told me he was born in 1989, which at the time put him in his late twenties. He had grown up near Empangeni, in rural KwaZulu-Natal, moving to Johannesburg in 2008 after finishing high school. He had a cousin living in this building, so it had become his home since. He had also worked a number 
of part-time jobs. In early 2014, the residents of Number 8 received an order to appear in court. The route to SERI, who would represent their case, proved circuitous: some of the residents of Ingelosi House, through social networks going back to home areas of KwaZulu-Natal, knew the occupants of a nearby building called Kiribilly, which had managed to resist eviction. It was the residents of Kiribilly who connected Number 8 with SERI. In time, their cases would become more closely connected than originally expected.

While SERI agreed to take on the case, it insisted, as usual, that the building form an elected committee. Mahlangu was voted onto that committee, and they managed to fight the case successfully. On April 16, 2018, the court ordered the City of Johannesburg to provide seventy-nine of the occupiers with "temporary shelter, from which they may not be evicted without a court order, in a location as near as possible to the property, by 31 October 2018." The court order was given on the same day as that regarding Kiribilly.

Kiribilly is a six-story high-rise in Berea, with a large palm tree outside, several blocks away from Ingelosi House. With 180 rooms, it is home to around 450 residents. The entry hall has an imposing art deco window curving toward a broken elevator. Its floors are adorned with graffiti. This building had stood at the center of a major Constitutional Court case in 2017. In 2013, the building owners had wanted to evict the residents, claiming the latter had agreed to their eviction. However, after seeking legal advice through SERI, the occupiers stated that they had not known their rights when agreeing to leave the building.

I visited Kiribilly in November 2018 with one of its committee members, Cikizwa Gqokoma, who also formed part of the leadership at the ICF. Gqokoma was born in 1983 in the Eastern Cape province and came to Johannesburg in 2005, where she lived with her five-year-old daughter. Her room was large, its walls painted pink, and she had an old television with a bunny-ears antenna. Her only water source came through a hosepipe connected in the street. She told me that most of the residents of the building were either Zulu or Xhosa, and there was a strong sense of community among them. But conditions were terrible - they had electricity, but no water, and no security. Criminals would frequently run inside the building to hide on the roof, and residents would be blamed by the police. The Kiribilly residents argued their Constitutional Court case on February 14, 2017, with the court ruling that the residents had assented to eviction with inadequate knowledge of their rights; their case on alternative accommodation was referred back to the High Court. It was heard together with the case of Ingelosi House. 


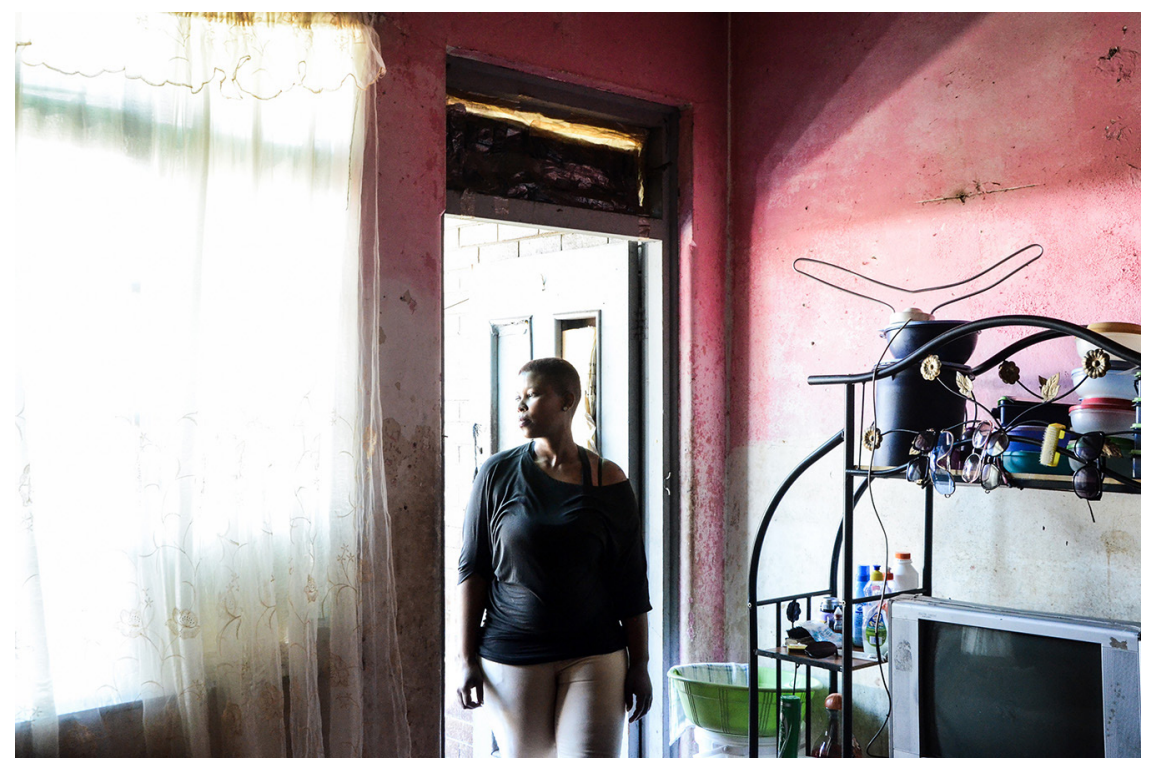

Figure 6. Cikizwa Gqokoma, one of the committee members of the Inner City Federation, in her room in Kiribilly, Berea. Photo by Matthew Wilhelm-Solomon, 2017.

The court ordered the eviction of Ingelosi and Kiribilly on the basis that the city would provide the residents who qualified, who would be rendered homeless, with alternative accommodation. Both buildings would be provided accommodation in the same place: Mahlangu and Gqokoma would become neighbors. It felt like a mixed victory for both: they would have alternative accommodation, but they would also be displaced from the buildings that had become their homes.

In spite of the Constitutional Court judgment, Mashaba's raids continued to target Kiribilly repeatedly. One, among several, was early 2018: Gqokoma recalls her and her daughter being woken up in the middle of the night by police and forced out of their rooms onto the street. The police insulted them and called them "hijackers." "I was angry," Gqokoma told me, "but there's nothing you can do, since it was a cop.”

Both Kiribilly and Ingelosi House were to become unknowingly tied to the condition of The Station - for the South African residents of The Station had also been allocated accommodation in the same temporary accommodation site in the nearby suburb of Jeppe. Yet further complications would arise, for local residents there had claimed that this building should be allocated to them for housing, and had threatened to attack any residents who moved in, which in turn prevented the 
relocations and evictions of Kiribilly, Ingelosi House, and The Station, a situation still ongoing at the time of writing.

\section{CONCLUSION}

The emergence of the ICF has shown the potentiality of residents of inner-city occupations to mobilize and form a critical consciousness around a shared condition. In their case this self-referentiality and organization moved toward a "right to the city" paradigm. However, the civic mobilization of the ICF emerged from ways of living otherwise in existing unlawful occupations, rather than preceding these occupations. Further, the form of potentiality I wish to show in terms of the city otherwise is not merely a potentiality for formal political organization. It is the potentiality to live and endure "otherwise" in relation to hegemonic forms of urban governance, in particular the protection of private property rights along with the policing of the nation-state.

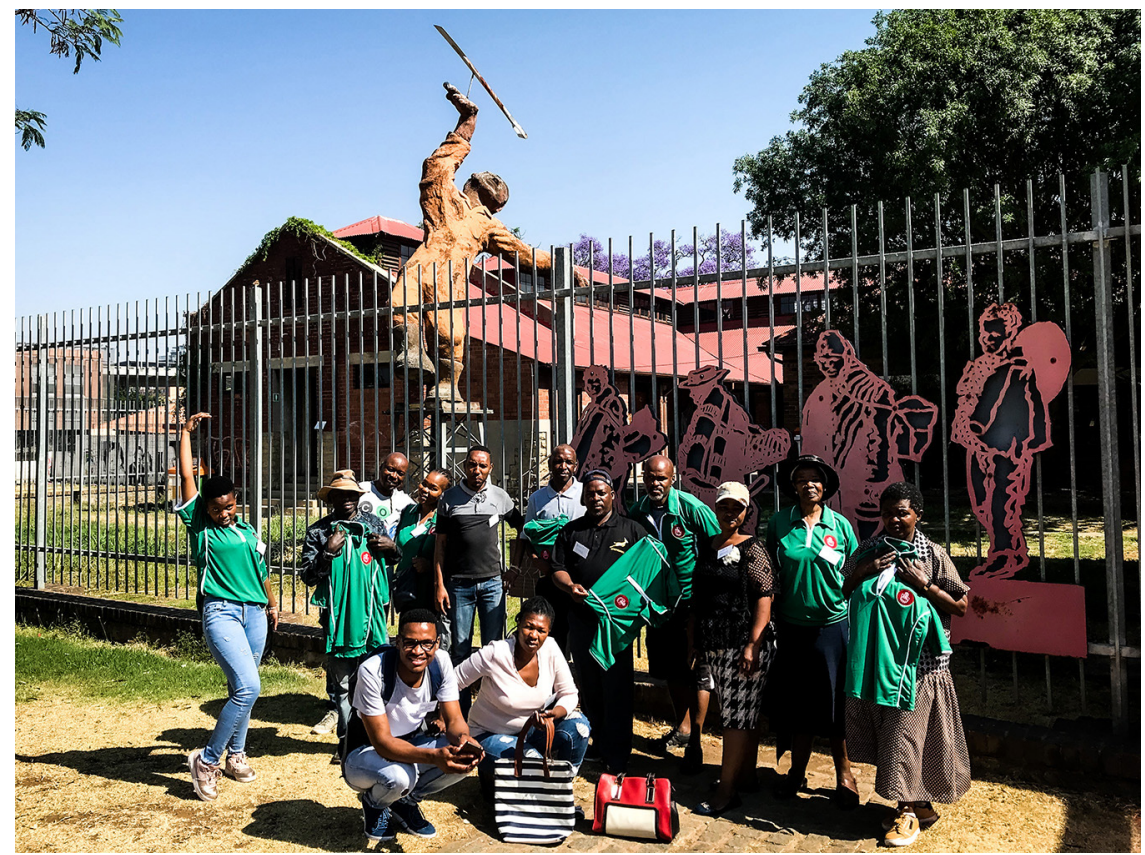

Figure 7. Members of the Inner City Federation outside the Worker's Museum in Newtown, 2019. Photo by Matthew Wilhelm-Solomon, 2019.

Povinelli views potentiality in terms of the duality of the oscillating potential "to be or not be." Povinelli (2011, introduction) writes: "If we must persist in potentiality, we must endure it as a space, a materiality, and temporality." Potentiality 
is "socially constituted and materially distributed," referring to a realm of "excess, exhaustion and endurance." These descriptions powerfully invoke the conditions of both those living in TEA and in unlawful occupations. This potentiality should not be evaluated simply in terms either of the privation of certain rights, or of some ideal form of commons or civic activism. Rather, it is a form of striving and endurance, and a mode of inhabiting the city otherwise, in ways that can manifest in formal civic action, but do not necessarily lead to this. What defines the politics of the otherwise is, then, the materialization of "alternative forms of life" and their persistence "in the gale force of curtailing social winds" (Povinelli 2011, introduction) - in the context of Johannesburg, these relate in particular to forms of endurance and occupation in the context of evictions, real-estate markets, deportations, and temporary emergency accommodation.

The concept of the city otherwise offers a distinct contribution to urban theory from theories of the commons or heterotopia and makes a contribution to assemblage theory. It captures the potentiality of alternate social projects without analyzing them in terms of either a transcendental or comparative concept (the "commons" or "participatory democracy"), or a given political trajectory. Rather, the political emerges from the otherwise and can take radically different formsthe striving to merely survive and endure under the constant threat of eviction and erasure (in the case of The Station), or in incipient social movements (illustrated by the ICF).

I have framed the emergence of the city otherwise in terms of the legal paradox of the deferred emergency. While I have traced this in relation to the specificities of post-apartheid law, it certainly could be adapted to other social and political contexts in which one finds a contradiction between private property rights, protections against eviction, and rights to relocation. Comparative legal regimes and experiences of occupation exist, for instance, in India (see Appadurai 2001; Chatterjee 2004) and Brazil (De Carli and Frediani 2016; Stevens 2017), among others, suggesting the possibility for further comparative research in future.

The case studies here - of Saratoga Avenue, Ekhuthuleni, The Station, Ingelosi House, and Kiribilly_ show how deeply interconnected these buildings are through forms of conviviality, jurisprudence, and TEA. Nonetheless, these interconnections sometimes remain invisible to the residents themselves. They are nets of sociality, law, and bureaucracy: from the gaps and possibilities in these, the city otherwise emerges. Unlawful occupations offer residents spaces in which they can "own" the city. And yet this ownership is always transient and uncertain, disrupted continually by police and immigration raids. For those who manage to 
access TEA, life within the aporias of constitutional law creates a space of the otherwise that provides protection against homelessness, but no offers of permanence. The deferred emergency creates a Zeno's paradox in which the emergency never comes - and so cannot, under present conditions, be resolved.

\title{
POSTSCRIPT
}

I finalized this article during the outbreak of the Covid-19 pandemic. Johannesburg, along with the rest of South Africa, was under a police- and army-enforced lockdown that started on March 26, 2020, after President Cyril Ramaphosa decreed a national state of disaster on March 15, 2020. While the public health impact in terms of slowing incidence has proven effective so far, inner-city Johannesburg residents, along with others in low-income areas of the country, have been particularly severely affected. Inner-city residents have been beaten with whips and shot at with rubber bullets in the streets. Dense living conditions and limited water supply mean that residents of occupations struggle to follow public health guidelines. Some, particularly undocumented migrants like those living at The Station, yet to be evicted, are short of food. The concatenation of the pandemic, the deferred emergency and the state of exception proper is unfolding with potentially dire consequences. - Matthew Wilhelm-Solomon, April 20, 2020

\begin{abstract}
This article draws on ethnographic fieldwork conducted in Johannesburg between 2011 and 2019 in inner-city unlawful occupations and temporary emergency accommodation sites. These are often referred to as "hijacked buildings," "bad buildings," or "dark buildings." However, they are also spaces of refuge, intimacy, and sociality for tens of thousands of South Africans and foreign nationals excluded from formal rental markets and often displaced by the drive for urban regeneration. This essay mobilizes two concepts to characterize these spaces. The first is the notion of the "city otherwise," engaging Elizabeth Povinelli's concept of "spaces of otherwise." The residents of these occupations endure in spaces of emergence and potentiality. Furthermore, I argue that they exist in a juridical condition that I characterize as "the deferred emergency." This condition entails the indefinite deferral of an emergency, framed around both the juridical and the infrastructural form of "temporary emergency accommodation" for the evicted. [Johannesburg; urban occupation; the otherwise; eviction; assemblage theory; emergency accommodation]
\end{abstract}

\section{NOTES}

Acknowledgments This essay was originally presented at the KU Leuven CADES debate, "The Politics of Presence and the Right to the City," at the invitation of Filip De Boeck and 
Ann Cassiman, and in conversation with Alexander Vasudevan in November 2017. A revised version was presented in October 2019 at the Wits Anthropology Seminar: my gratitude goes to the students and colleagues at these events for their valuable responses, and particularly to Eric Worby for his incisive personal comments. This article draws on research conducted at the African Centre for Migration and Society as part of "Knowledge for Tomorrow-Cooperative Research Projects in Sub-Saharan Africa," funded by the Volkswagen Foundation in collaboration with Lorena Nuñez and Peter Kankonde, along with Hansjörg Dilger of the Institute of Social and Cultural Anthropology at the Freie Universität, Berlin (2013-2016), and the Wellcome Foundation - supported Migration and Health Project Southern African (2016-2017), led by Jo Vearey. The essay was completed at Wits Department of Anthropology. Thank you to the Inner City Federation and Socio-Economics Rights Institute of South Africa for their research engagement between 2017 and 2019; to Sam Sadian for his friendship, input, and editing; to my wife, Adriana Miranda da Cunha, for the continuing conversations and support; to the Cultural Anthropology editors (Christopher Nelson, Heather Paxson, and Brad Weiss) and the anonymous reviewers for their invaluable input, and to Jessica Lockrem for facilitating the review and production process. Finally, my deepest appreciation goes to all those who shared their time, spaces, and stories with me. This essay is dedicated to the memory of Nomusa Mabaso (1965-2019) and her injunction to me not to forget.

1. A Zimbabwean herself, fluent in several Southern African languages, who has asked to remain unnamed.

2. I have anonymized the names of most interlocutors and of the location and name of The Station. TEA sites, along with Ingelosi House and Kiribilly, are named as they are already in the public domain through public court records and with approval from their representatives. Nomsa Dladla's name, along with those of the leaders of the Inner City Federation, is used with written permission. Photographs, even when names are altered, are used with informed consent. Nomusa Mabaso's name is used in her memory.

3. I have not referenced these, as doing so would breach the anonymity of one of my field sites, to which they refer.

4. Povinelli's is not the only conceptualization of the term otherwise. In addition to Awan (2016), Rike Sitas (2020), in an article published after the acceptance of this article, develops her own notion, not derived from the work of Povinelli, of "becoming otherwise" based on "artful urban inquiry" and "experimental pedagogical politics." Zimitri Erasmus (2017) has also developed her own distinct notion of the "otherwise" in relation to race and creolization in post-apartheid South Africa.

5. The full name of the case is City of Johannesburg Metropolitan Municipality v Blue Moonlight Properties 39 (Pty) Ltd and Another (CC). The judgement, as documented by the Southern African Legal Information Institute, is available at http://www.saflii.org/za/cases/ ZACC/2011/33.pdf (accessed March 10, 2019).

6. The full name of the case is Dladla and Another $v$ City of Johannesburg and Others. The judgement, as documented by the Southern African Legal Information Institute, is available at http://www.saflii.org/za/cases/ZACC/2017/42.pdf (accessed March 10, 2019).

7. These included, among others, the Inner City Resource Centre, Planact, and Doctors Without Borders (MSF).

\section{REFERENCES}

Agamben, Giorgio

1999 Potentialities: Collected Essays in Philosophy. Edited and translated, with an introduction, by Daniel Heller-Roazen. Stanford, Calif.: Stanford University Press.

2005 State of Exception. Translated by Kevin Attell. Chicago: University of Chicago Press. 
Allison, Anne, and Charles Piot

Appadurai, Arjun

2014 “Editors' Note on 'Neoliberal Futures.” Cultural Anthropology 29, no. 1: 3-7. https://doi.org/10.14506/ca29.1.02.

2001 “Deep Democracy: Urban Governmentalityand the Horizon of Politics.” Environment Awan, Nishat and Urbanization 13, no. 2: 23-43. https://doi.org/10.1177/095624780101300203.

2016 Diasporic Agencies: Mapping the City Otherwise. London: Routledge.

Berlant, Lauren

2016 “The Commons: Infrastructures for Troubling Times." Environment and Planning D: Society and Space 34, no. 3: 393-419. https://doi.org/10.1177/0263775816645989.

Biehl, João, and Peter Locke

2017 "Foreword: Unfinished." In Unfinished: The Anthropology of Becoming, edited by João Biehl and Peter Locke, ix-xii. Durham, N.C.: Duke University Press.

Bochow, Astrid, and Rijk Van Dijk

2012 "Christian Creations of New Spaces of Sexuality, Reproduction, and Relationships in Africa: Exploring Faith and Religious Heterotopia: A Special Issue of the Journal of Religion in Africa." Journal of Religion in Africa 42, no. 4: 325-44. https://doi. org/10.1163/15700666-12341235.

Chance, Kerry Ryan

2015 "'Where there is fire, there is politics': Ungovernability and Material Life in Urban South Africa." Cultural Anthropology 30, no. 3: 394-423. https://doi.org/10.14506/ ca30.3.03

Chatterjee, Partha

2004 The Politics of the Governed: Reflections on Popular Politics in Most of the World. New York: Columbia University Press.

Das, Veena

2017 “Comments.” Current Anthropology 58, no. 2: 176-77. https://doi.org/10.1086/ 691162.

De Boeck, Filip, and Sammy Baloji

2016 Suturing the City: Living Together in Congo's Urban Worlds. London: Autograph ABP.

De Carli, Beatrice, and Alexandre Apsan Frediani

2016 "Insurgent Regeneration: Spatial Practices of Citizenship in the Rehabilitation of Inner-City São Paulo." GeoHumanities 2, no. 2: 331-53. https://doi.org/10.1080/2 373566x.2016.1235984.

Dirsuweit, Teresa, and Alex Wafer

2016 "Suburban Road-Closures and the Ruinous Landscapes of Privilege in Johannesburg." Social Dynamics 42, no. 3: 395-410. https://doi.org/10.1080/025 33952.2016.1237321.

Dugard, Jackie, and Makale Ngwenya

2018 "Property in a Time of Transition: An Examination of Perceptions, Navigations and Constructions of Property Relations among Unlawful Occupiers in Johannesburg's Inner City." Urban Studies 56, no. 6: 1165-81. https://doi.

Erasmus, Zimitri org/10.1177/0042098018765402.

2017 Race Otherwise: Forging a New Humanism for South Africa. Johannesburg: Wits University Press.

Farías, Ignacio

2011 “The Politics of Urban Assemblages." City 15, nos. 3-4: 365-74. https://doi.org/ 10.1080/13604813.2011.595110.

Farías, Ignacio, and Anders Blok

2016 "Introducing Urban Cosmopolitics: Multiplicity and the Search for a Common World." Urban Cosmopolitics: Agencements, Assemblies, Atmospheres, edited by Anders Blok and Ignacio Farías, 1-22. London: Routledge. 
Fassin, Didier, Matthew Wilhelm-Solomon, and Aurelia Segatti

2017 "Asylum as a Form of Life: The Politics and Experience of Indeterminacy in South

Foucault, Michel Africa." Current Anthropology 58, no. 2: 160-87. https://doi.org/10.1086/691162.

1986 “Of Other Spaces.” Diacritics 16, no. 1: 22-27. https://doi.org/10.2307/464648.

Gqola, Pumla Dineo

2015 Rape: A South African Nightmare. Johannesburg: Jacana Media.

Harrison, Philip, Graeme Gotz, Alison Todes, and Chris Way

2014 "Materialities, Subjectivities and Spatial Transformation in Johannesburg." In Changing Space, Changing City: Johannesburg after Apartheid, edited by Philip Harrison, Graeme Gotz, Alison Todes, and Chris Way, 2-39. Johannesburg: Wits University Press.

Harvey, David

2008 "The Right to the City." New Left Review 53: 23-40. https://newleftreview.org/ issues/II53/articles/david-harvey-the-right-to-the-city.

Hoffman, Danny

2017 Monrovia Modern: Urban Form and Political Imagination in Liberia. Kindle ed. Katumba, Samy Durham, N.C.: Duke University Press.

2019 “Gauteng's Ward Level Racial Diversity: 2018." Gauteng City-Region Observatory, February 28. http://www.gcro.ac.za/outputs/map-of-the-month/detail/gautengsward-level-racial-diversity-2018/.

Landau, Loren

2011 "Introduction: Exorcising the Demons Within: Xenophobia, Violence, and Statecraft in Contemporary South Africa." In Exorcising the Demons Within: Xenophobia, Violence and Statecraft in Contemporary South Africa, edited by Loren Landau, 1-25. Johannesburg: Wits University Press.

Lefebvre, Henri

1996 Writings on Cities. Edited by Eleonore Kofman and Elizabeth Lebas. Oxford: Blackwell.

Mashaba, Herman, and Isabella Morris

2017 Black Like You: An Autobiography. Johannesburg: Bookstorm.

Mbembe, Achille, and Sarah Nuttall

2008 "Introduction: Afropolis." In Johannesburg: The Elusive Metropolis, edited by Sarah Nuttall and Achille Mbembe, 1-33. Johannesburg: Wits University Press.

McFarlane, Colin

2011a “Assemblage and Critical Urbanism." City 15, no. 2: 204-24. https://doi.org/10.1 080/13604813.2011.568715.

2011b Learning the City: Knowledge and Translocal Assemblage. Oxford: Wiley-Blackwell.

Miranda da Cunha, Adriana

2019 "Estéticas transversais em Thwala: Um teatro feminista africano." In Práticas artísticas: Participaçāo e communidade, edited by Huga Cruz, Isabel Bezelga, and

Mkokeli, Sam Ramon Aguiar, 464-92. Lisbon: Universidade de Évora.

2017 “Johannesburg Mayor Insists on 'Shock and Awe' Plan for City." Bloomberg, August 14. https://www.bloomberg.com/news/articles/2017-08-14/johannesburg-mayorMosselson, Aidan insists-on-shock-and-awe-plan-for-city.

2019 Vernacular Regeneration: Low-Income Housing, Private Policing and Urban Transformation Murray, Martin J. in Inner-City Johannesburg. London: Routledge.

2008 Taming the Disorderly the City: The Spatial Landscape of Johannesburg after Apartheid. Ithaca, N.Y.: Cornell University Press. 
Olga, Lafazani

2013 “A Border within a Border: The Migrants' Squatter Settlement in Patras as a Heterotopia." Journal of Borderlands Studies 28, no. 1: 1-13. https://doi.org/10.108 0/08865655.2012.751731.

Oloukoï, Chrystel

2018 “Precarious Gentrification: Dreading the Night While 'Taking Back the City' in Johannesburg." In Exploring Nightlife: Space, Society and Governance, edited by Jordi Perdigon, Sylvain Nofre and Adam Eldridge, 19-34. London: Rowman and Littlefield.

2015 “For us it is otherwise': Three Sketches on Making Poverty Sensible in the Palestinian Refugee Camps of Lebanon.” Current Anthropology 56, no. S11: S88S96. https://doi.org/10.1086/682354.

2017 “Comments." Current Anthropology 58, no. 2: 181-83. https://doi.org/10.1086/ 691162.

Povinelli, Elizabeth A.

2011 Economies of Abandonment: Social Belonging and Endurance in Late Liberalism. Kindle ed. Durham, N.C.: Duke University Press.

2014 "Geontologies of the Otherwise." Theorizing the Contemporary, Fieldsights, January 13. https://culanth.org/fieldsights/geontologies-of-the-otherwise.

2016 Geontologies: A Requiem to Late Liberalism. Durham, N.C.: Duke University Press. Ralph, Michael

2008 "Killing Time." Social Text 4, no. 97: 1-29. https://doi.org/10.1215/016424722008-008

RebelGroup

2016 Johannesburg Inner City Housing Strategy and Implementation Plan 2014-2021. Documents obtained by the author through personal communication.

Redfield, Peter

2013 Life in Crisis: The Ethical Journey of Doctors without Borders. Berkeley: University of California Press.

SERI (Socioeconomic Rights Institute of South Africa) and ICF (Inner City Federation)

2018 "Inner City Federation: Fighting for Decent Housing in Inner-City Johannesburg." Johannesburg: SERI. https://www.seri-sa.org/index.php/more-news/856new-publication-seri-launches-new-community-practice-note-on-inner-cityfederation-30-november-2018.

Simone, AbdouMaliq

2004 "People as Infrastructure: Intersecting Fragments in Johannesburg." Public Culture 16, no. 3: 407-29. https://doi.org/10.1215/08992363-16-3-407.

2014 Jakarta, Drawing the City Near. Minneapolis: University of Minnesota Press.

2019 Improvised Lives: Rhythms of Endurance in an Urban South. Cambridge, UK: Polity.

Sitas, Rike

2020 "Becoming Otherwise: Artful Urban Enquiry." Urban Forum 2020: 1-19. https:// doi.org/10.1007/s12132-020-09387-4.

Skosana, Ina

2017 “Mayor's Claim_-Undocumented Foreigners Make Up 80\% of Joburg Inner City_-Absurd."' Africa Check, September 7. https://africacheck.org/reports/ Stevens, Jeroen mayors-claim-80-joburg-inner-city-residents-undocumented-foreigners-absurd/.

2017 “Occupied City: Hotel Cambridge and Central São Paulo between Urban Decay and Resurrection." In From Conflict to Inclusion in Housing: The Interaction of Communities, Residents and Activists, edited by Graham Cairns, Georgios Artopoulos, and Kirsten Day, 23-39. London: UCL Press.

Vasudevan, Alexander

2017 The Autonomous City: A History of Urban Squatting. London: Verso Books. 
Vearey, Joanna

2010 "Hidden Spaces and Urban Health: Exploring the Tactics of Rural Migrants Navigating the City of Gold." Urban Forum 21: 37-53. https://doi.org/10.1007/ s12132-010-9079-4.

Wafer, Alex

2017 "Loitering: Reassembling Time in the City-of-the-Global-South." Social Dynamics 43, no. 3: 403-20. https://doi.org/10.1080/02533952.2017.1390876.

Wanjiku Kihato, Caroline

2014 Migrant Women of Johannesburg: Everyday Life in an In-Between City. Johannesburg: Wits University Press.

Wilhelm-Solomon, Matthew

2016 "Decoding Dispossession: Eviction and Urban Regeneration in Johannesburg's Dark Buildings." Singapore Journal of Tropical Geography 37, no. 3: 378-95. https:// doi.org/10.1111/sjtg.12165.

2017 "The Ruinous Vitalism of the Urban Form: Ontological Orientations in InnerCity Johannesburg." Critical African Studies 9, no. 2: 174-91. https://doi.org/10.10 80/21681392.2017.1337520.

2020 "Affective Regenerations: Intimacy, Cleansing, and Mourning in and around Johannesburg's Dark Buildings.” In Affective Trajectories: Religion and Emotion in African Cityscapes, edited by Hansjörg Dilger, Astrid Bochow, Marian Burchardt, and Matthew Wilhelm-Solomon, 29-51. Durham, N.C.: Duke University Press.

Wilhelm-Solomon, Matthew, and Jens Pedersen

2017 "Crossing the Borders of Humanitarianism: Médecins Sans Frontières (MSF) in Inner-City Johannesburg." Urban Forum 28: 5-26. https://doi.org/10.1007/s12132016-9285-9.

Wilkinson, Kate

2016 “ANC's 5 Million House Claim an 'Error/Typo.” Africa Check, March 1. https:// africacheck.org/reports/ancs-5-million-house-claim-an-typoerror/.

Wilson, Stuart

2013 "Curing the Poor: State Housing Policy in Johannesburg after Blue Moonlight." Constitutional Court Review 5: 280-96. https://constitutionalcourtreview.co.za/ volume-v-2013/.

Worby, Eric

Forthcoming "The Time of the Commons and the Subject of the South." In Contested Subjectivities in the Global South, edited by Georgina Cebey, Susanne Goumegou, and Sebastian Thies. New York: Routledge. 